DOI https://doi.org/10.30525/978-9934-26-173-2-26

\title{
ОСОБЛИВОСТІ ФОРМУВАННЯ МОРАЛЬНИХ ЦІННОСТЕЙ МАЙБУТНІХ ПЕДАГОГІВ
}

\author{
Безбородих С. М. \\ кандидат педагогічних наук, \\ завідувачка кафедри туризму, готельної і ресторанної справи, \\ дочент кафедри дошкільної та початкової освіти \\ Д3 «Луганський національний університет імені Тараса Шевченка»

\section{Мороз В. П.} \\ кандидат педагогічних наук, \\ доиент кафедри педагогіки, \\ дочент кафедри спеиіальної та інклюзивної освіти \\ Д3 «Луганський національний університет імені Тараса Шевченка» \\ м. Старобільськ, Луганська область, Украӥна
}

Теорія цінностей основана на взаємозв'язку об'єктивного характеру наукових, соціальних, моральних, естетичних та інших цінностей, їх залежності від історичних умов суспільних відносин.

Моральні цінності в житті суспільства виступають соціально значущими орієнтирами діяльності суб'єктів. Ці цінності становлять фундамент культури, який визначається через їх систему та ідеї, що слугують для регулювання поведінки членів даного соціуму [1].

До моральних цінностей можна віднести явища суспільної свідомості, які відображають інтереси у формі добра і зла, справедливості та несправедливості, моральних нормативів та принципів. Ці форми $\epsilon$ нормативними за своїм характером, визначають явища реальності, вимагають їх здійснення або відчуження від них, виносять їм оцінку, схвалюють їх або засуджують.

Виходячи з вище викладеного, моральні иінності - це соціальні визначення об'єктів навколишнього світу, що визначають їх позитивне або негативне значення для окремої людини або суспільства (добро, зло, добробут, прекрасне тощо).

У моральних ціннісних орієнтаціях відбиваються уявлення людини про добро і зло, щастя та горе, любов та ненависть, за допомогою яких людина може оцінити конкретні життєві ситуації, вчинки інших та власну поведінку. Вони фіксують певне ставлення людини до явищ i процесів життя, яке виражає засудження або схвалення. Моральні 
ціннісні орієнтації є одним із засобів розвитку особистості, методологічним підгрунтям морального виховання [1].

Зазначимо, що мораль є підгрунтям особистості. Людська душа, вважає I. Степаненко, не скерована духом, сформованим на етичних засадах, залишається «темною пучиною вод» (К. Юнг), яка може вийти 3 «берегів» і цілком поглинути людину, зруйнувати іiі особистість $[2$, c. 47]. Педагог зобов'язаний бути особистістю з високоморальними якостями, зразком для дітей, авторитетом для батьків та колег, носієм не тільки загальноприйнятої моралі, але й моралі педагогічної, яка складається з системи норм і вимог щодо його поведінки.

Місце моральних цінностей у структурі особистості майбутнього педагога визначається значущістю професійної діяльності. Для формування моральних цінностей значний потенціал має навчальновиховне середовище 3ВО, яке створює сприятливі умови для всебічного розвитку й саморозвитку особистості, наповненню моральними цінностями суб'єктів навчання й виховання; підсилює взаємостосунки; сприяє засвоєнню соціального досвіду й набуттю якостей, необхідних людині для життя тощо.

Формування моральних цінностей майбутніх педагогів в умовах 3ВО може впроваджуватися різними взаємодоповнюючими засобами: введенням спеціальних курсів, через гуманізацію змісту загальноосвітніх та професійних освітніх компонентів, самоосвіту тощо.

Найбільш ефективними для формування моральних цінностей майбутніх педагогів $\epsilon$ колективні творчі справи; використання проектних, рефлексивних, інтерактивних, інформаційно-комунікативних технологій.

Пріоритетними у цій роботі вважаються: методи формування свідомості особистості (бесіди, розповіді, пояснення, диспути, дискусії, читання наукової літератури, метод прикладу); методи організації діяльності й формування досвіду суспільної поведінки (громадська думка, громадське доручення, створення виховних ситуацій, безпосередня участь у громадському житті); методи стимулювання поведінки й діяльності (метод проблемних ситуацій, змагання, моральні й матеріальні заохочення).

Таким чином, сформовані моральні цінності майбутнього педагога зумовлюють вибір засобів досягнення мети, встановлення стосунків з іншими на основі взаємоповаги та взаєморозуміння. 


\title{
Література:
}

1. Власенко О. М. Проблема формування моральних цінностей майбутніх учителів у теорії і практиці професійної освіти. Освіта Донбасу. 2004. № 3 - 4. С. 87 - 93.

2. Степанов О. М., М. М. Фіцула. Основи психології і педагогіки: навч. посібник. 2-е вид., випр., доп. К.: Академвидав, 2005. 520 с.

DOI https://doi.org/10.30525/978-9934-26-173-2-27

\section{ПРОФЕСІЙНЕ ВДОСКОНАЛЕННЯ: УНІВЕРСИТЕТСЬКИЙ ПРОСТІР}

\author{
Голос Г. А. \\ доктор філософії, \\ стариий викладач кафедри германської філологї \\ Київський університет імені Бориса Грінченка \\ м. Київ, Україна
}

Постановка проблеми. У XXI столітті проблема формування фахівця важко вирішується без продуктивного партнерства усіх учасників освітнього процесу. Все більше постає розуміння важливості налагодження такої взаємодії між здобувачами і викладачем, що дефакто часто подібне до традиційних «знаннєнакопичувальних» практик. Проблема, яку висвітлює стаття: співтворчість, партнерство, взаємодія студентської молоді і викладача - незмінні константи плідного навчаннявикладання у вищій школі, джерело обопільного впливу учасників освітнього процесу один на одного в контексті професійного росту.

Стан дослідження. Теоретичні аспекти професійного становлення фахівця, професійного вдосконалення педагога розкрито у публікаціях зарубіжних і вітчизняних науковців: висвітлено психологічно-педагогічні аспекти професіоналізації особистості, проаналізовано проблеми професійного самовизначення особистості, виокремлено етапи професійного становлення, подано досвід професійного становлення майбутніх фахівців у різних закладах вищої освіти (A. Glatthorn, D. Schon, Л. Долинська, Л. Жовтан, О. Мазко, О. Пісоцька, О. Савченко) $[1 ; 2 ; 4 ; 5 ; 7 ; 8 ; 9 ; 10]$. Серед широкого спектру проблем професійного вдосконалення, що піднімаються авторами, недостатньо висвітленою залишається феноменологія взаємовпливу викладач-студент, що спонукає до пошуку нових практик професійного вдосконалення. 